\title{
Translation Study of Refusal Strategy in Beautiful Malice Novel (A Pragmatic Approach)
}

\author{
Wyut Yee Soe \\ Myanmar University of Dagon, Myanmar
}

\begin{tabular}{l} 
Article Info \\
\hline Article history: \\
Submitted July 11, 2018 \\
Revised Aug 15, 2018 \\
Accepted November, 2018 \\
Published November 21, 2018
\end{tabular}

Keywords:

Refusal Strategy

Translation Quality

Translation Technique

\begin{abstract}
The study aims to explore the translation techniques and translation quality of refusal strategy in Beautiful Malice novel. It employs a descriptive qualitative method with embedded case study. The data was obtained through content analysis and focus group discussion. They were then analyzed into domain, taxonomy and componential analysis to formulate cultural theme. The result shows that the author of the novel uses both indirect and direct refusal strategies with the former being the most used startegy. On the other hand, the translator deals with these refusal strategies through the use of a number of translation techniques namely established equivalence, modulation, explicitation, variation, implicitation, pure borrowing, reduction, addition, addaptation, and paraphrase. The most used translation technique is established equivalence. The study indicates that the translation quality is very good. They are 2.8 of accuracy and 2.9 of acceptability and readablity. Imperfection of translation quality is affected from the use of reduction and addition in relation to accuracy and the use of deletion in relation to those aspects of translation quality.
\end{abstract}

\section{Corresponding Author:}

Wyut Yee Soe,

Universitas Sebelas Maret, Surakarta, Indonesia

Jl. Ir. Sutami 36 A, Kentingan, Surakarta, Indonesia.

Email: wyutyeesoe333@gmail.com

\section{INTRODUCTION}

Novel is one of the most popular genre in modern literature. However, the reader's limitation in accessing the language in which the novelist write the novel makes translation an important means of bridging the divide between languages. Translation does not only mediate between different languages, but also cultures. This phenomenon makes translation a rather complex and challenging process which require translators not to only be bilingual but more importantly interculturally competent.

Refusal strategy is a communication competence to say 'No' of something which is arguably different in relation to different society and culture. On one hand, one's society and culture prefer to refuse others' by directly saying 'No'. On the other hand, other's society and culture prefers to refuse indirectly by giving reason, asking for excuse, etc. Some studies on refusal strategies has revealed that the use of direct and indirect strategy on refusing suggestion, request, invitation and offer is related to certain context like social status, age and relationship or distance (Aliakbari \& Changizi, 2012; Chojimah, 2015; Li \& Sun, 2015; Sarfo, 2011). However, those didn't show different context in terms of social and culture. 
Another studies on using different refusal strategy has accounted that language proficiency gives impact positively and negatively (Abed, 2011; Gol, 2013; Morkus, 2009; Sa'd \& Qadermazi, 2014; Tanck, 2004). They found that someone who are native can refuse correctly while non-native cannot. This indicates that social and cultural background have different strategy in expressing refusal. Consequently, people from one society and culture will probably express idea, act or even behave incorrectly in others'.

Since the way people in different culture refuse differently, it is interesting to carry this study out into translation point of view. Translation refers to transferring meaning from source text into target text. It deals with using the very equivalent and natural terms in TT (Nida \& Taber, 1982). A study on translation studies has revealed how translator transfer face threatening act from ST to TT (Agustina, Nababan, \& Djatmika, 2016). This study has been revealed that one of speech act which threaten others' face is refusal. However, it didn't focus on refusal strategy. The study focusing on refusal strategy has revealed that there were 3 strategy used including direct, indirect and combination in which those were related to some speech act (refusal set) (Rusjayanti, 2016). However, the strategy found is too general. Therefore, this study tries to investigate refusal strategy deeply by employing refusal strategy theory proposed by Beebe, Takahashi, Uliss-Weltz, Scarcella, \& Elaine (1990).

With the employment of Beebe et al., (1990) theory, this study give insight about how English uses refusal strategy deeply. Besides, this study also investigates how translator transfers those strategies into target culture with reference to Molina \& Albir (2002) theory and how it give impact to translation quality with respect to translation quality assessment as proposed by (Nababan, Nuraeni, \& Sumardiono, 2012).

\section{THEORY AND METHODS}

Translation refers to process and product. Process deals with the process of transferring meaning from ST to TT, while product refers to the result of that process. It also cannot be separated from art, skill and science (Nababan, 2016). Art indicates that ST has an element of art which has to be avoided from removing it. Skill implies that translator has to have skill in transferring meaning from ST to TT. Science refers to technique and methodology in transferring meaning. Nevertheless, those are not significant if translator doesn't know for whom translation is.

Additionally, there are many ways to translate ST to TT. Molina \& Albir (2002) proposes 18 translation techniques including adaptation, amplification, borrowing, calque, compensation, description, discursive creation, established equivalent, generalization, linguistic amplification, linguistic compression, modulation, particularization, reduction, substitution, transposition and variation. Those are not good or bad themselves because it depends on context taken place. If translator uses certain technique in the right context and situation, the application of that technique results in good quality of translation and vice versa.

Moreover, to test if translation quality is good or bad is by using translation quality assessment. There are so many assessment proposed by experts, but it is only Nababan et al., (2012) who propose the complete assessment. The assessment include accuracy, acceptability and readability. Accuracy refers to the equivalence of meaning in ST and TT. Acceptability deals with rules, norms and culture in TT. Readability is related to reading comprehension. If reader can comprehend text easily, it indicates that text has a high level of readability. For each assessment aspect, they determines 1-3 scale representing good, average and bad in which 3 is the highest score. 
Furthermore, translation is not only about reproducing meaning in different languages. It also covers social and cultural aspects. Both social and cultural aspects determine people to communicate one another. This is also has been accounted as a favorable pitfall in communication across culture and society. Communication of people with different background of society and culture frequently lead to pragmatic failure. It reflects by expressing speech act incorrectly in terms of context playing a role.

Speech act accommodates many expression for communication. The expression which accommodate people to refuse known as refusal. It deals with suggestion, request, invitation and offer (Searle, 1969). The way people to refuse refers to strategies. There are two strategies in refusing others' suggestion, request, invitation and offer including direct and indirect refusals (Beebe et al., 1990). To refuse others' directly is to say 'no' or to express negative willingness or ability. Besides, to refuse others' indirectly is to use statement of regret, to wish something, to excuse, to give reason and explanation, to use statement of alternative, to set condition for acceptance, to let interlocutor off the hook, to express postponement, to switch the topic, to repeat, to give self-defense, to express of having lack of empathy, to express joke and to criticize. The choice of refusal strategies is related to social distance, social status, and severity of the act (Brown \& Levinson, 1987)

The study employed descriptive qualitative with embedded case study. It deals with investigating phenomenon of languages especially English and Indonesian. The data includes primary and secondary data. The primary data were refusal strategies from Beautiful Malice Novel (James, 2010) and its Indonesian version Kekejaman yang Indah (James, 2011), translation technique and quality of refusal strategy. The secondary data were related studies. They were obtained through content analysis and focus group discussion. Content analysis referred to obtaining refusal strategy and its translation techniques, and developing translation quality data. Focus group discussion dealt with obtaining translation quality data from raters. They were then analyzed by domain, taxonomy and componential analysis to formulate cultural theme (Santosa, 2017) of translation technique and quality of refusal strategy in Beautiful Malice and Kekejaman yang Indah.

\section{FINDINGS AND DISCUSSION}

\section{Refusal Strategy in Beautiful Malice Novel}

Based on the analysis conducted, the study shows that both direct and indirect refusal strategies are used. However, the direct one is the most favorable strategy. The result is shown in the following table.

Table 1. Refusal Strategy in Beautiful Malice Novel

\begin{tabular}{clcc}
\hline \multicolumn{1}{c}{ Refusal Strategy } & F & \% \\
\hline \multirow{2}{*}{ D } & No & 42 & 46,15 \\
\cline { 2 - 4 } & Negative willingness/ability & 25 & 27,47 \\
\hline \multirow{3}{*}{ I } & Statement of regret & 4 & 4,40 \\
\cline { 2 - 4 } & Wish & 1 & 1,10 \\
\cline { 2 - 4 } & Excuse, reason, explanation & 13 & 14,29 \\
\cline { 2 - 4 } & Statement of Alternative & 3 & 3,30 \\
\cline { 2 - 4 } & Set condition for acceptance & 2 & 2,20 \\
\cline { 2 - 4 } & Let Interlocutor off the hook & 1 & 1,10 \\
\hline \multicolumn{2}{c}{ Total } & 91 & 100 \\
\hline
\end{tabular}

From the table 1: D - Direct refusal, I - Indirect refusal, F - Frequency and \% - Percentage. 
Table 1 shows that the ST writer mostly exploits direct refusal strategies by directly saying 'No' (46.15\%) and indirect refusal strategy by excusing, reasoning and explaining (14.29\%). For example:

Data BM.06

Context : Katherine suggesting Alice to go travelling

Katherine : "I can think of a few good things about it. Swimming in the Mediterranean, seeing the Eiffel Tower, the Great Wall of China, the Statue of Liberty ... and not knowing anyone. Imagine how liberating that must be."

Alice

: "Nah. I like it here."

Data BM.07

Context

: Katherine's mother offers Katherine to live with them.

Katherine's mother : “... For me. You could live with us, and you know how pleased Daddy would be if you did that, and you could really concentrate on your studies without rents or bills or your meals. We could take care of you, make it all easier."

Katherine

: "I don't know Mom. I don't know."

From the examples above, Alice and Katherine use different refusal strategies. In data BM.06, Alice refuses Katherine's suggestion to go travelling directly by saying 'Nah'. In data BM.07, Katherine refuses her mother's offer indirectly. She gives her mother a reason why she can make Alice come to their house.

\section{Translation Techniques of Refusal Strategy}

After examining the refusal strategies employed in Beautiful Malice, the refusal strategies used in Kekejaman yang Indah were analysed and compared to those used by the ST author in order to identify the translation techniques used. These techniques are shown in the table below.

Table 2. Translation Technique of Refusal Strategy

\begin{tabular}{lcc}
\hline \multicolumn{1}{c}{ Translation Techniques } & F & \% \\
\hline Established Equivalence & 184 & 56,44 \\
\hline Variation & 35 & 10,74 \\
\hline Modulation & 30 & 9,20 \\
\hline Explicitation & 29 & 8,90 \\
\hline Implicitation & 14 & 4,29 \\
\hline Pure borrowing & 9 & 2,76 \\
\hline Addition & 9 & 2,76 \\
\hline Reduction & 7 & 2,15 \\
\hline Deletion & 4 & 1,23 \\
\hline Transposition & 2 & 0,61 \\
\hline Paraphrase & 2 & 0,61 \\
\hline Adaptation & 1 & 0,31 \\
\hline \multicolumn{1}{c}{ Total } & 326 & 100 \\
\hline
\end{tabular}

Table 2 shows that there are 12 translation techniques used in translating refusal strategies from ST into TT. The established equivalent strategy is the most used strategy. 
From 91 instances of refusal strategies, the translator uses 326 translation techniques. This indicates that the translator often uses more than one translation technique in dealing with a refusal strategy. For example:

Data BM.14

ST : :No. I'm Katherine, just Katherine."

TT : "Tidak. Namaku Katherine. Panggilanku Katherine."

Data BM 04

ST : "I'm not interested in travelling."

TT : :Lagi pula, aku tak tertarik jalan-jalan ke luar negeri."

From the examples above, in data BM.14 the translator uses four translation techniques including established equivalence, modulation, pure borrowing and explicitation. "No" is translated by using established equivalence because it is considered a very common word. Modulation is used to translate I into Nama (name). I, which literally means saya is modulated lexically in which originally means saya. Katherine is retained in TT without any change of spelling or pronunciation or standardized TT grammar. Last, then is explicitly transferred into panggilanku. The translator gives explicit information related to Katherine as a nickname. In example BM.04 the translator uses four translation techniques including addition, variation, established equivalent and explicitation. Addition is used by adding lagi pula which doesn't represent any words in ST. Variation is used to transfer not into tak as another variation of tidak. Established equivalent is used to translate $I$ and interested in in which its translation $a k u$ and tertarik is considerably familiar. Lastly, explicitation is used to transfer travelling into jalan-jalan ke luar negeri. In this case, translator states explicitly place where speaker is not going to travel.

\section{Translation Quality of Refusal Strategy}

Based on the focus group discussion and the translation quality assessment instrument used, the quality of the translation of the refusal strategies in terms of accuracy, acceptability and readability is as follows.

\begin{tabular}{|c|c|c|c|c|c|c|}
\hline RS & \multicolumn{2}{|c|}{ TQ } & $\mathbf{F}$ & & \multicolumn{2}{|l|}{ TQA } \\
\hline \multirow[t]{9}{*}{ D } & A1 & A & 58 & 2.79 & 2.82 & 2.88 \\
\hline & & LA & 4 & & & \\
\hline & & IA & 5 & & & \\
\hline & A2 & A & 62 & 2.85 & & \\
\hline & & LA & - & & & \\
\hline & & IA & 5 & & & \\
\hline & $\mathrm{R}$ & $\mathrm{H}$ & 62 & 2.85 & & \\
\hline & & M & - & & & \\
\hline & & $\mathrm{L}$ & 5 & & & \\
\hline \multirow[t]{9}{*}{ I } & A1 & A & 21 & 2.88 & 2.94 & \\
\hline & & LA & 3 & & & \\
\hline & & IA & - & & & \\
\hline & A2 & A & 24 & 3.00 & & \\
\hline & & LA & - & & & \\
\hline & & IA & - & & & \\
\hline & $\mathrm{R}$ & $\mathrm{H}$ & 24 & 3.00 & & \\
\hline & & M & - & & & \\
\hline & & $\mathrm{L}$ & - & & & \\
\hline
\end{tabular}


RS - Refusal Strategy, TQ - Translation Quality, TQA - Translation Quality Average, A1 Accuracy, A2- Acceptability, $R$ - Readability, A - Accurate/Acceptable, LA - Less Accurate/Acceptable, IA - Inaccurate/Inacceptable, H - High Level of Readability, M Medium Level of Readability and L - Low Level of Readability.

Table 3 shows that indirect refusal strategy has a better quality of translation than direct one. It is reflected by translation quality average indicating direct refusal of 2.82 and indirect refusal of 2,94. Additionally, translation quality assessment deals with accuracy, acceptability and readability in which each of them divides into three scales including 3 for high quality, 2 for medium quality and 1 for low quality. For example:

Data BM.14

ST : : "No. I'm Katherine, just Katherine."

TT : : "Tidak. Namaku Katherine. Panggilanku Katherine.

Data BM.85

ST : "Doesn't matter. I don't want talk. I want to have some fun."

TT : :Tak masalah. Aku tak minat ngobrol. Aku senang-senang."

Data BM.77

ST : :I don't want to."

TT : -

The examples above show different translation quality. Data BM.14 shows accurate, acceptable and high level of readability or translation quality average of 3 . It implies that translation has no meaning distortion, natural and easy to understand. Data BM.85 shows less accurate, acceptable and high level of readability. It means that translation has distortion of meaning but still natural and easy to undertand. The meaning distortion is reflected by reducing some meaning of I want to have some fun. Data BM.77 shows inaccurate, inacceptable and low level of readability. It indicates that the meaning in TT is deleted, unnatural and difficult to undertand. It is resulted from deleting meaning in TT.

\section{Relationship of Refusal Strategy, Translation Technique and Translation Quality}

Furthermore, the use of translation techniques affects its translation quality. The study shows that the employment of certain technique gives both positive and negative impacts. It is shown in the following table.

Table 4. Relationship of Refusal Strategy, Translation Technique and Translation Quality

\begin{tabular}{|c|c|c|c|c|c|c|c|c|c|c|c|c|c|c|c|}
\hline \multirow[t]{2}{*}{ RS } & \multicolumn{12}{|c|}{ Translation Technique } & \multicolumn{3}{|c|}{$\begin{array}{c}\text { Translation } \\
\text { Quality }\end{array}$} \\
\hline & $\mathbf{E E}$ & $\mathbf{V}$ & $\mathbf{M}$ & $\mathbf{E}$ & I & PB & $\mathbf{A}$ & $\mathbf{R}$ & D & $\mathbf{T}$ & $\mathbf{P}$ & Ad & A1 & A2 & $\mathbf{R}$ \\
\hline D & 135 & 19 & 22 & 19 & 14 & 6 & 5 & 5 & 4 & 2 & 1 & 1 & 2.79 & 2.85 & 2.85 \\
\hline I & 49 & 16 & 8 & 10 & - & 3 & 4 & 2 & - & - & 1 & - & 2.87 & 3.00 & 3.00 \\
\hline$\sum$ & 184 & 35 & 30 & 29 & 14 & 9 & 9 & 7 & 4 & 2 & 2 & 1 & 2.8 & 2.9 & 2.9 \\
\hline
\end{tabular}

From the table: EE - Established Equivalent, $V$ - Variation, $M$ - Modulation, E-Explicitation, $I$ - Implicitation, PB - Pure Borrowing, A - Addition, $R$ - Reduction, D - Deletion, $T$ Transposition, $P$ - Particularization, Ad - Addaptation.

Table 4 shows that the use of translation technique affects its translation quality. Direct refusal is affected in all aspect of translation quality while indirect refusal only gets impact 
in terms of accuracy. The negative impact is reflected by the use of reduction, addition and deletion. It is shows that every utterances employing reduction and addition resulted in less accurate translation. For example:

Data BM.59

ST : “No, It can't matter because we're friend and we're looking after each other and we're not hurting Alice."

TT : " "Tidak. Tak mungkin jadi masalah karena kita berteman dan kita saling menjaga perasaan masing-masing.

Data BM.12

ST : Boring.

TT : Ah, membosankan.

In Example BM.59 the ST is translated using the established equivalent, modulation, explicitation and reduction techniques. By reducing the bold clause above, accuracy of translation negatively is affected. Translation shows less accurate due to distortion of meaning in TT. In addition, data BM.12 is transferred by addition and established equivalent. Translator adding $A h$ in TT which is categorized as pause filler of adjunct refusal. As Beebe, et al (1990) claim, adjunct refusal is included into indirect refusal. While ST version shows one strategy of refusal, TT one shows two. It indicates that translator gives different intention with writer and results in less accurate translation. However, both data BM.59 and BM.12 don't get negative impact in terms of acceptability and readability. Those reflect acceptable translation and have high level of readability. This indicates that translation is familiar and readers have no difficulties to read it.

Besides, deletion technique also give negative impact in all aspect of translation quality. The application of deletion technique results in inaccurate, inacceptable and low level of readability. For example:

Data BM. 68

ST : "No. Thanks"

TT : -

From the example above, translator uses deletion technique. This techniques is sub category of reduction technique. It refers to removing information from ST to TT. In the context above, translator remove information about direct refusal in TT. Consequently, translation quality get negative impact. It is reflected in inaccurate and inacceptable translation as well as a low level of translation readability.

Nevertheless, there are also translation techniques which give positive impact to translation quality, including established equivalence, variation, modulation, explicitation, implicitation, pure borrowing, transposition, paraphrase and adaptation. The application of those result in accurate translation, acceptable translation and high level of readability. For example:

Data BM.24

ST : :No. She didn't say it, but it's pretty obvious."

TT : "Tentu saja tidak. Tidak dikatakan, tapi cukup jelas." 


\section{Data BM.42}

ST : "No way. God, no. Give me a little more credit than that."

TT : :Tidak mungkin. Amit-amit, tidak. Seleraku belum separah itu."

From the examples above, data BM.24 is transferred by using explicitation, established equivalent and modulation while data BM.42 uses established equivalent, adaptation and modulation. Both data BM.24 and BM.42 shows accurate translation in relation to the absent of meaning distortion. Acceptable translations are reflected by familiar and usual wording and structure in TT. Last, high level of readability is considerably affected by the easiness of readers in reading translations.

\section{CONCLUSION}

After conducting the study, it is found that there are two strategies used by writer in showing refusal. They are direct and indirect refusals. From those, there are sub categories in which each categories is dominated by 'No' of direct refusal and excusing, reasoning and explaining of indirect one. Additionally, after comparing refusal strategy in ST and TT, it is found 12 translation techniques applied, and established equivalent is the most favorable one. The application of translation techniques give both positive and negative impact to translation quality. Reduction, addition and deletion negatively affect translation quality.

At the micro linguistic level, a translation technique such as deletion and addition might seem to distort the linguistic accuracy of translation. But at the more macro level of pragmatics and culture, such techniques might have been employed deliberately to create a particular effect on the reader, e.g. to match the dialogic/conversational style of the target language and culture. So, the question here is how do we define translation quality? What is it that determines whether a translation is of good or bad quality? A way of answering this question is to go back to the purpose of the translational act. What was the purpose of translating that novel? Was it simply to entertain readers who did not have linguistic access to the ST? Is it to expose the target readers to the culture of the ST? and the list goes on. Based on such purposes, the techniques used at the micro linguistic level could differ significantly.

\section{REFERENCES}

Abed, A. Q. (2011). Pragmatic Transfer in Iraqi EFL Learners' Refusals. International Journal of English Linguistics (Vol. 1).

Agustina, M. D., Nababan, M. R., \& Djatmika. (2016). Analisis teknik dan kualitas terjemahan kalimat yang merepresentasikan tuturan mengancam muka negative in the adventure of Sherlock Holmes. Prasasti: Journal of Linguistics, 1(2), 305-324.

Aliakbari, M., \& Changizi, M. (2012). On the realization of refusal strategies by Persian and Kurdish speakers. Intercultural Journal of Intercultural Relations, 36(5), 659-668.

Beebe, L. M., Takahashi, T., Uliss-Weltz, R., Scarcella, R. C., \& Elaine. (1990). Pragmatic Transfer in ESL Refusals. Developing Communicative Competence in a Second Language. New York: Newburry House. (R. C. Scarcella, E. S. Anderson, \& S. D. Krashen, Eds.). New York: Newburry House.

Brown, P., \& Levinson, S. C. (1987). Politeness: some universals in language usage. Cambridge: Cambridge University Press. 
Chojimah, N. (2015). Refusal and politeness strategies in relation to social status: a case of face-threatening act among indonesian university students. Theory and Practice in Language Studies, 5(5), 906-918. https://doi.org/http://dx.doi.org/10.17507/tpls.0505.04

Gol, N. K. Z. (2013). A Contrastive Study of the Speech Act or Refusal; Iranian ESL Learners and Native English Speaking Americans. University of Toledo.

James, R. (2010). Beautiful Malice. New York: Bantam Books.

James, R. (2011). Beautiful Malice (Kekejian yang Indah). Jakarta: Pustaka Bahtera.

Li, X., \& Sun, J. (2015). A Pragmatic Study in Refusal Strategies by Chinese College Nursing Majors. Cambridge Journal of China Studies, 10(2), 67.

Molina, L., \& Albir, A. H. (2002). Translation Techniques Revisited : A Dynamic and Functionalist Approach. Meta: Translators' Journal, XLVII(4), 498-512.

Morkus, N. (2009). The Realization of the Speech Act of Refusal in Egyptian Arabic by American Learners of Arabic as a Foreign Language Dissertation: University of South Florida.

Nababan, M. (2016). Menerjemah bahasa Inggris. Yogyakarta: Pustaka Pelajar.

Nababan, M., Nuraeni, A., \& Sumardiono. (2012). Pengembangan model penilaian kualitas terjemahan. Kajian Linguistik Dan Sastra, 24(1), 39-57.

Nida, E. A., \& Taber, C. R. (1982). The theory and practice of translation. Leiden: E.J. Brill.

Rusjayanti, A. (2016). Analisis terjemahan kalimat yang merepresentasikan tuturan penolakan dan rangkaiannya (refusal set) pada novel the deception point dan dampaknya terhadap kualitas terjemahan (Sebuah Pendekatan Pragmatik). Universitas Sebelas Maret.

Sa'd, S. H. T., \& Qadermazi, Z. (2014). Refusal Strategies of Iranian University English as a Foreign Language and Non-English Learners in Native Language: A Comparative Study. CEPS Journal, 4, 121-142.

Santosa, R. (2017). Metode penelitian kualitatif kebahasaan. Surakarta: UNS Press.

Sarfo, E. (2011). Variations in Ways of Refusing Request in English among Members of a College Community in Ghana. African Nebula, 3, 1-15.

Searle, J. (1969). Speech acts. Cambridge: Cambridge University Press.

Tanck, S. (2004). Speech Act Sets of Refusal and Complaint: A Comparison of Native and Non-native English Speakers' Production. TESOL Working Papers, 2, 1-22. 
